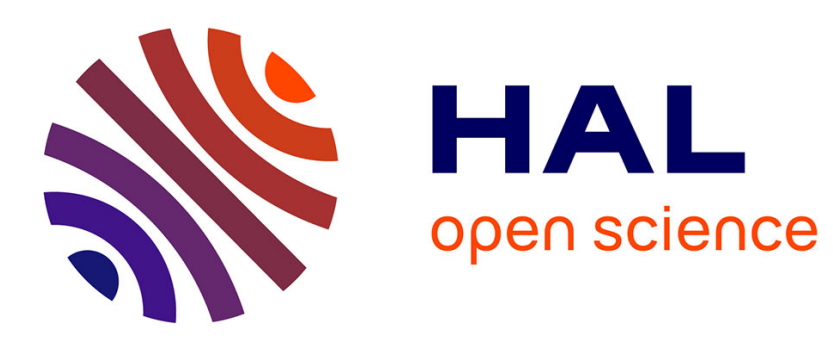

\title{
Becoming the next Charlie Parker : Rewriting the role of passions in bureaucracies with Whiplash
}

\author{
Dirk Lindebaum, Courpasson David
}

\section{To cite this version:}

Dirk Lindebaum, Courpasson David. Becoming the next Charlie Parker : Rewriting the role of passions in bureaucracies with Whiplash. Academy of Management Review (The), 2019, 44 (1), 227-239 p. hal-02276728

\section{HAL Id: hal-02276728 \\ https://hal.science/hal-02276728}

Submitted on 3 Sep 2019

HAL is a multi-disciplinary open access archive for the deposit and dissemination of scientific research documents, whether they are published or not. The documents may come from teaching and research institutions in France or abroad, or from public or private research centers.
L'archive ouverte pluridisciplinaire HAL, est destinée au dépôt et à la diffusion de documents scientifiques de niveau recherche, publiés ou non, émanant des établissements d'enseignement et de recherche français ou étrangers, des laboratoires publics ou privés. 
BECOMING THE NEXT CHARLIE PARKERT: REWRITING THE ROLE OF PASSIONS IN BUREAUCRACIES WITH WHIPLASH

\begin{tabular}{|r|l|}
\hline Journal: & Academy of Management Review \\
\hline Manuscript ID & AMR-2017-0414-RE \\
\hline Manuscript Type: & Review Essay-By Invitation Only \\
\hline Theoretical Perspectives: & Bureaucracy, Commitment, Control, Power \\
\hline Topic Areas: & \\
\hline Abstract: & \\
\hline & \\
\hline
\end{tabular}

SCHOLARONE ${ }^{\text {m }}$

Manuscripts 


\title{
BECOMING THE NEXT CHARLIE PARKER ${ }^{\dagger}$ : REWRITING THE ROLE OF
}

PASSIONS IN BUREAUCRACIES WITH WHIPLASH

\author{
Dirk Lindebaum ${ }^{1 *}$ \\ Cardiff Business School, UK \\ mail@dirklindebaum.EU \\ www.dirklindebaum.EU \\ David Courpasson $^{2}$ \\ EM Lyon, France \\ and \\ Cardiff Business School, UK \\ courpasson@em-lyon.com
}

Keywords: bureaucracy, passions, performance, violence, voluntary servitude

Cite as:

Lindebaum, D. \& Courpasson, D. (2017) Becoming the next Charlie Parker: Rewriting the role of passions in bureaucracies with Whiplash. Academy of Management Review.

Please do not cite without permission until the essay has undergone copy-editing by the journal.

\footnotetext{
Notes and Acknowledgements

${ }^{1}$ Drummer -retired; ${ }^{2}$ Drummer - active

${ }^{\dagger}$ In the movie, Charlie Parker is a frequently invoked name of a prodigy jazz musician who entered stardom after initial setbacks, much like the protagonist in the movie Whiplash. We use the reference to Charlie Parker a metaphor of a certain idea of the best possible musician, rather than an instance of how to become the best musician - either as a soloist or as part of an ensemble. For background on this story, see

http://www.newyorker.com/culture/richard-brody/whiplash-getting-jazz-right-movies , accessed on $5^{\text {th }}$ of June 2017.

* Both authors contributed equally to this essay.

We gratefully acknowledge the insightful comments provided by Rick Delbridge, Martin Kornberger and Deanna Geddes on earlier versions of this essay. The editor Jean Bartunek provided superb conceptual guidance throughout the revision process, and we wish to place an explicit 'thank you' on record for that. With his prior experience as a jazz drummer, her brother Tom provided insightful comments on the framing of the metaphor around Charlie Parker.
} 
Despite previous work developing an understanding of organizational violence through grounded theoretical frameworks (Clegg, 2006; Hearn, 1994), we still do not understand the extent to which the conscious practice of violence in bureaucracies can influence subsequent individual performance. Part of the problem is that the 'talk about' violence at work is so heavily fraught with negative connotations that theoretical and empirical efforts about its potential utility (see also Lindebaum, 2017), such as driving excellent performance at work, are oftentimes suppressed. In consequence, accounts on the potential utility of violence at work remain essentially under-explored within management and organization studies. However, the fact that we do not talk much about violence in management and organization studies cannot be taken as in indicator that it is not present, as classical management accounts have shown (Terkel, 1974).

The lack of engagement with violence as a construct of theoretical and practical relevance poses significant challenges for management and organization studies ${ }^{3}$. As Albrow (1992) reminds us, bureaucratic organizations revolve around emotional politics; their central purpose is to remove and suppress any unpredictable behavior that is an outcome of passionate drivers, so as to build a safe and rational world devoid of anger, violence and love. However, studies of bureaucracies show that it is an endless and hopeless quest for purity and neutrality (Gouldner, 1954). Bureaucracy ends up shaping the parameters of human existence in ways far more closely than anything Weber might have imagined. What is puzzling, though, is that organizational scholarship often discounts the significance of the passionate side of bureaucracies by systematically insisting upon its dispassionate and rule-driven side. As Graeber (2012) puts it, "it's almost as if the more we allow aspects of our everyday existence to fall under the purview of bureaucratic regulations, the more everyone concerned

\footnotetext{
${ }^{3}$ We want to be absolutely clear that we do not personally advocate physically violent workplaces. Workplaces have often legal obligations - for very good reasons - to prevent physical harm for employees. At the same time, we do not pretend that only because it is legally sanctioned or negatively 'talked about', that it does not occur at work.
} 
colludes to downplay the fact (perfectly obvious to those actually running the system) that all of it ultimately depends on the threat of physical force" (p. 112). Thus, we see passions not as abstract and free-floating entities, but as concrete interactional processes in which physical violence, and the threat of violence ${ }^{4}$, can play a constitutive role (Confortini, 2006). In that respect, despite prior influential work on the informal sides of bureaucracies (Gouldner, 1954), it remains obscure how bureaucracies can be something other than impersonal mazes alienating and destroying human capacities. In other words, how can bureaucracies be approached as places where individuals can achieve great things and cultivate a passion for their work, even if it involves violence?

In this essay, we aim to analyze the role of passions when they are inscribed in practices of violence, as drivers for exceptional performance, such as becoming the next Charlie Parker (or researcher, employee or soldier). While we elaborate further upon this later, we note here that this focus is relevant to management and organization studies for one specific reason: it enables a better understanding of the dynamics around the conscious practice of violence - and its passionate manifestations - in bureaucracies that can drive subsequent individual and organizational performance. As we argue later, the conscious practice of violence does not imply here that it is inflicted upon the victim against his/her will, but is rather consciously accepted by the victim as a necessary experience toward excellence. Our argument stands at an angle with the literature on work passion and bureaucracies. For one thing, it contrasts with the view that work passion represents "a psychological state characterized by the experience of intense positive emotions, an internal drive to do the work, and a sense of meaningful connection toward one's work" (Perttula \& Cardon, 2011:193, italics added). For another, it stands in direct contrast to the lingering

\footnotetext{
${ }^{4} \mathrm{We}$ focus here on the direct observation of physical violence, admitting the possibilities that there is also psychological violence at play in the movie upon which this essay focuses. It is, however, outside the scope of this essay to give detailed attention to both due to the multifaceted manifestations of psychological violence, such as public humiliation, bullying or invoking maladaptive guilt.
} 
domination within organizational scholarship of a Weberian image of the passionless bureaucracy. To this end, we derive inspiration from the award-winning movie Whiplash. We do so because the movie offers rich and fresh insights into how violence and passion can help explain - under certain circumstances - the everyday quest for excellent performance within bureaucracies.

\section{AN OVERVIEW OF WHIPLASH}

The movie's storyline is situated in an elite jazz music college in the US, where some of the best musical students are enmeshed in a violent game to become world-class musicians. Central to the movie is the initially antagonistic relationship between the drumming prodigy Andrew Neiman (played by Miles Teller) and his psychopathic Jazz music instructor Terence Fletcher (played by J. K. Simmons). Being a recognized jazz drummer virtually means the world to Andrew, and so he commences his musical 'apprenticeship' with great zeal and discipline, putting in the 'extra effort' (i.e., extracurricular practice) to succeed. With such keen eye on his drumming practice, he progressively struggles in the movie to maintain healthy social relationships around him, be it with his father (who grows increasing unease about his son's ambition) or his girl-friend (who he at some point considers a liability to his ambition and dumps her). With his peers too, he does not connect much on the social level. For instance, his ambition evokes scorn when another drummer is promoted to core drummer instead of him, and the fact that he misplaced the notes of yet another drummer just before a gig does not earn him the respect from his peers (especially not as in the latter case Andrew actually benefits from the misplaced notes because he can play the piece by heart).

At this juncture, it is key to highlight that Andrew's passion goes beyond 'harmonious passions', which refers to situations in which individuals voluntarily and willingly accept work as personally and unconditionally meaningful (Vallerand et al., 2003). While Andrew 
also exhibits harmonious passions, his craving for the teacher's approval ${ }^{5}$ also implies that lines are crossed into what is described as obsessive passions, where individuals feel compelled to engage in work to sustain their sense of social acceptance, self-esteem, or feelings of excitement (Vallerand et al., 2003).

During an extracurricular practice session at the very beginning of the movie, he gets a surprise visit from Terence Fletcher in the rehearsal room. Andrew instantly exhibits highly reverent behavior toward Terence ("Yes, Sir! or "Sorry, Sir . . "), though it cannot be established retrospectively whether that is the result of pure admiration and respect for the teacher, or the recognition of Terence's terrifying and brutal 'teaching style' to elicit the best skills from his students. As the movie progresses, however, it becomes clear that woe betides any student whose performance falls below Terence's mighty expectations; Terence does not hesitate to berate, humiliate, or physically assault students in light of such failures, (e.g., shouting accusingly at students "are you sabotaging my band"? in response to one instrument being out of tune, or throwing chairs at Andrew). His approach to motivating students is tellingly captured in a key quote of the movie with Terence speaking to Andrew in the Jazz bar: "There are no two words more harmful in the English language than 'good job", . Terence readily, and with no remorse, plays on the hopes (and fears) of his student to get what is for him the ultimate goal (i.e., "to push people [the students at the college], not conducting!"). In the pursuit of this goal, he "will never apologize for how [he tries] to get the next Charlie Parker".

Terence plays mind games with Andrew (Travers, 2014). This works because Andrew is exceptionally aspirational, if not obsessive in nurturing his own drum-beating talent and

\footnotetext{
${ }^{5}$ Consider, for instance, the final scene when Terence signals that approval to Andrew through a nod. We discuss that scene later in our essay.

${ }^{6}$ This is a key scene of the movie. Andrew had been kicked out of the jazz conservatory for having physically attacked Terence after a performance during which he could not play well due to injuries incurred minutes before the gig as a result of a car crash. In turn, Andrew testifies, on condition of anonymity, that he suffered at the hand of Terence's violent teaching style. This leads to Terence's dismissal from the music school. The meeting in the bar was a chance meeting months after the dismissals described above.
} 
status. He has a 'personal stake' in the task and institution at hand (cf. Lindebaum \& Ashkanasy, 2017 and ; Voronov \& Weber, 2016), and dedicates his life and body to an everyday exhausting training, relentlessly repeating the same gestures up to the point of bleeding hands. He continuously looks for the additional technical detail that will make a difference. There is blood on the drum kit - (Terence: "Alternates, wipe the blood of my drums set"). Yet, Andrew's aspiration is also his weakness; it renders him emotionally susceptible to manipulation and attack. Thus, he enters a relationship characterized by sustained violence inflicted upon him by his teacher. Terence is very resourceful in challenging Andrew, needling him and setting him up to eventually knock him down again. What looks perhaps on the surface as inspirational discipline and cunning provocation on the part of Terence regularly crosses the line into outright violence.

A shallow watching of the movie would suggest that Andrew is forced into a relationship of compulsory dependence and subjugation by Terence. But that is not the case. For one thing, Terence sees the potential in Andrew to become the next Charlie Parker. Andrew, in a sense, personifies for Terence the combination between passionate dedication to work and subjugation to the harshness often characteristic of bureaucracies. Director Damien Chazelle suggested in an interview that Terence has this "unabating. . . just . . . pure love for the music" $"$. For another thing, the subjugation can only unfold as long as it is permitted by Andrew, himself entirely focused on becoming the best. Therefore, Andrew holds considerable power in his hands, which he at first does not grasp at all, only at a later stage in the movie (see final section of this essay). Nevertheless, both are locked in claustrophobic corporeal interaction and dependence at the beginning and middle of the movie, like two boxers fighting in the ring. How this physical violence will end up in a miraculously creative musical achievement, however, is the core topic of the movie.

\footnotetext{
${ }^{7}$ Retrieved from https://www.theguardian.com/film/2015/jan/12/whiplash-jk-simmons-miles-teller, accessed on $5^{\text {th }}$ of June 2017.
} 
One of the most intriguing and bewildering insights of this movie is that the 'best' drumming is elicited through sustained violence in which Andrew seems to voluntarily coopt. Our contention is that the music school (i.e., as one manifestation of a bureaucracy) permits the construal of violence as a condition for the passage into excellence, by galvanizing the student's passion to be the best and giving meaning to his disciplinary subjugation. By the same token then, violence can be theorized as a creative and dynamic relationship as much as a mere practice of univocal domination.

Before we proceed, we need to clarify that Whiplash is more than a piece of fiction. In terms of its genesis, it is meaningfully informed by the first-hand experience of the Director Damien Chazelle getting drum lessons himself ${ }^{8}$. We can, therefore, infer that there is a degree of pragmatic validity reflected in the movie, described as a "criterion for establishing truth as fulfilment in practice" (Sandberg, 2005: 54). Likewise, J. K. Simmons was also outspoken in an interview that Terence's violent practices are often observable amongst music instructors and conductors ${ }^{9}$. And finally, one commentator argued that the character of Terence Fletcher resembled strongly the legendary jazz drummer and bandleader Buddy Rich, who, in a secret recoding, berated his musicians aboard their tour bus after a show: "Everybody can hear your $f^{* * * * * '}$ clams out there! If I hear one $f^{* * * * * '}$ clam from anybody, you've had it! One clam and this whole $f^{* * * * * '}$ band is through!" ${ }^{\prime \prime}$. Accordingly, Whiplash has representational character in terms of its depiction of violence as a means to breed champions in the context at hand. In other words, the movie invites greater attention to the variety of effects violence can have in the workplace given different contextual circumstances (Johns, 2017).

\footnotetext{
${ }^{8}$ Retrieved from http://www.rollingstone.com/movies/reviews/whiplash-20141009, accessed on the $5^{\text {th }}$ of June 2017.

${ }^{9}$ Retrieved from https://www.youtube.com/watch? $\mathrm{v}=7 \mathrm{eEuds} 1$ Qtqk , accessed on the 5th of June 2017. This story also lends a degree of credibility to the movie, see http://www.thepurchasebeat.com/purchase-getswhiplash-conservatory-students-react-to-a-hard-hitting-film/ , retrieved on $19^{\text {th }}$ of July 2017.

${ }^{10}$ Retrieved from https:/www.theguardian.com/film/2015/jan/12/whiplash-jk-simmons-miles-teller , accessed on the $6^{\text {th }}$ of January 2017.
} 
In the remainder of this review essay, we first unpack in more detail the relevance of Whiplash and the insights it generates to help advance our substantive understanding of violence, passions and their consequences in bureaucracies. Second, we lay the conceptual foundations of violence by explaining what it is, but also, perhaps more importantly, how it can produce excellent performance at work. We should not shy away from studying violence at work, especially but not limited to physical violence, as we have clarified already. Despite the topic perhaps appearing as 'undesirable', the reality may be that, given the right constellation of individuals at a specific moment in time and space, violence may be observable and prove to have utility in these circumstances. Third, equipped with these insights, we then map out the need to re-write the role of passions in bureaucracies, away from the traditional view of bureaucracies as sober and dispassionate arenas, toward the view of passions constituting the very life-blood without which excellent performance is an ambitious yet often unfulfilled goal in certain circumstances. Finally, we turn to the final scene in order to close the narrative around Andrew's path toward becoming the next Charlie Parker. We relate the movie's final scene, in synthesizing fashion, to prior discussions in this essay on violence, passion, and excellent performance within bureaucracies.

\section{RELEVANCE OF WHIPLASH FOR MANAGEMENT RESEARCH AND PRACTISE}

We contend that Whiplash offers a unique window into better understanding the processes that explain how violence can be - under certain circumstances - a productive force in the pursuit of individual excellence in bureaucracies. Readers might object that the conservatory may at first glance have nothing to do with what Weber described as an 'administration'. Indeed, the movie does not give details on its internal functioning. However, we propose that 
the conservatory qualifies as a bureaucracy for three reasons. First, the centrality of technical expertise that is illustrated by the obsessive repetition of exercises, and the necessity of absolute perfection, shines through on numerous occasions in the movie. This speaks to what Gabrielsson (2001) calls the 'musical structure', made of tempo, loudness, pitch, intervals, and rhythms. The obsessively perfect musical structure of the elite orchestra driven by Terence is a reflection, we argue, of the aspiration of bureaucracies of achieving tasks in the most perfect and impersonal manner. Thus, technical expertise is key in sustaining the musical ensemble. Second, what is central in Weberian thinking is the power of discipline. The harshness of discipline is the heart of the efficiency observable within bureaucracies, efficiency being define here as the capacity of the conservatory to produce some of the best jazz musicians. To be among them, students must be able to keep the right tempo, be on time, obey the teachers' orders, and relentlessly repeat the same gestures to guarantee the perfect performance. And third, a central ingredient that permits us to treat bureaucracy as a core phenomenon in our essay is the legitimacy of authority (Gouldner, 1954). The movie is largely illustrative of the legitimacy of Terence (the bureaucrat in this case) as asserting the organizational and institutional right to apply any method or rule that permits the achievement of the collective enterprise (i.e., producing the best musicians for the sake of the best ensemble). Combining these three aspects, we believe the conservatory context and its effects on the students' ensemble is a clear instance of the power and discipline that characterize bureaucracies. The remainder of our essay should be read with this explanation in mind.

Having clarified why we consider the jazz conservatory a bureaucracy, we propose that Whiplash affords an analysis of a specific way of channeling energies toward excellent performance that has been neglected so far by management and organization studies. In that respect, Whiplash helps us shed fresh lights on the literature on bureaucracies in two 
significant ways. First, it shows how the everyday practice of violence at work can drive learning and excellent performance. To this end, the movie partly connects with existing studies on brutal bosses (Hornstein, 1996) ${ }^{11}$ and willing victims (Lipman-Blumen, 2005). Terence's brutality seems gratuitous, as it manifests itself when he throws a chair at Andrew, or indeed when he slaps him multiple times in the face because he fails to play the correct tempo. On the other hand, Andrew does not resist the sustained physical violence inflicted by Terence throughout much of the movie, because he knows that it is his ordeal that he has to live through courageously if he wants to become the next Charlie Parker. Put differently, Whiplash alerts us to the presence of an under-exposed - yet vitally important - phenomenon that we can observe in many aspects of management research and practice, namely, that of voluntary servitude. It expresses the fact that any form of influence or domination, no matter how ruthless or despotic, rests on the willingness of the majority of the people (or specific individuals, as in the case of Andrew). This consent is not a natural production, but is engineered and carefully supported by astute propaganda and the mystique of power (de la Boétie, 1975/2008). The potency of voluntary servitude in informing management research is such that it can explain individual aspirations for excellent performance in ways often neglected in this discipline. In other words, we argue that voluntary servitude is a concept that can help better explain certain surprising reasons for accepting violent conduct of individuals with power and status beyond the immediate objection that subjugation may be unconsciously internalized over time.

Whiplash offers a fascinating story through which voluntary servitude comes to light in a concrete organizational context, such as high-commitment educational settings (whether a music, art, business school or the military). Voluntary servitude can thus be enlisted as a

\footnotetext{
${ }^{11}$ We also note that José Mourinho, coach of Manchester United, tends to develop a "politics of injury, of capacity and human will" for the sake of "winning at all costs" (Ronay, 2016). The article suggests a conditioning of players to accept a kind of athletic masochism, consisting of playing despite (or because) of injury.
} 
means aiding bureaucracies to strive for more efficient means to breed champions (e.g., doctoral students or early career researchers), thereby enlarging the organization's reputation. Thus, the role of voluntary servitude within bureaucratic organizations in shaping the learning process (and subsequent excellence) manifests itself, underlining prior studies arguing that "greater attention [should] be given to the forms of social interaction and the context in which learning takes place" (Cajiao \& Burke, 2016: 509). Shedding light on the performative interaction between brutal bosses and willing victims, Whiplash shows how violence can be fully inscribed in the socialization of how individuals (with varying roles, such as teacher or student) fit into existing power structures that serve the interests of elite teachers and/or organizations, as well as of those students who are capable of 'making it'. If this is embraced by students, it helps illustrate how students (as willing victims) sacrifice their dignity and wellness in the pursuit of lofty ambitions. It also suggests that this apparently submissive behavior is inscribed in the very functioning of the whole organization, thereby linking violence to the very efficiency of the school's curricula.

Second, Whiplash permits a new reading of how passions influence the efficient reproduction of bureaucracies (here, the music college). These are usually analyzed as power systems that tone down, and even largely undermine, passion ${ }^{12}$. Indeed, the music college confirms the Weberian thesis according to which bureaucracies are terrific machines to produce efficiency (i) through administration based on technical expertise and (ii) administration based on discipline (Gouldner, 1954). While both feature prominently in Whiplash $^{13}$, we note the intriguing nexus of technical competence, harsh discipline and detailed guidance from the teacher with how Andrew's passion pushes him to voluntarily

\footnotetext{
${ }^{12}$ For a powerful counter-perspective, see de Tocqueville (1889/2002) and Albrow (1992).

${ }^{13}$ For instance, Terence cements his authority through technical expertise by being able to detect a single out-oftune instrument in the whole jazz band, or being able to detect the finest nuances between 'dragging' or 'rushing' the tempo on the drum. Likewise, Terence's explicit expectation for rigorous discipline shines through on numerous occasions in the movie (e.g., "If you want the f****** part, earn it!"), or when he summons Andy to a 6am individual practice session (at which he himself does not show up).
} 
submit to the authority of Terence. In consequence, Whiplash shows that Andrew's passage to excellence is not accomplished in a dispassionate and cold-blooded world of discipline and rules. On the contrary, the efficiency of the jazz conservatory rests upon carnal and emotionladen interactions that shape everyday life at work. Seen in this light, bureaucracies appear as largely driven by passions, contrary to the still dominant Weberian vulgate. The movie indeed reveals that an elite bureaucracy, where technical expertise and discipline are central, also encompasses a variety of passionate and exceptional interpersonal encounters. For instance, when Andrew is seemingly not performing according to Terence's high standards during a band rehearsal (Terence's discontent is expressed through a tirade of insults), Terence eventually asks Andrew “Are you upset?", to which Andrew replies "Yes", to which Terence in turn responds "LOUDER!", to then have the shattered Andrew reply "YES!". Thus, passions help us speak about bureaucracies (such as schools or the military) in a wider context, including the possibility that extraordinary performance can be produced by phenomena that habitually carry 'negative' connotations (see Lindebaum, Jordan, \& Morris, 2016; Smith, 2007 for what this can imply in the military context). The absence of passion, or the analysis of passion as a problem for management because it complicates control over individual motives to engage or disengage, is why theorists often cast bureaucracies as dehumanizing places, cultivating thoughtless rule-following that is contradicting individuals' taking of responsibility for what they do (see e.g., Fromm, 1941/2011). Whiplash suggests that it might be more complex than that.

\section{THE FABRIC OF PRODUCTIVE VIOLENCE}

According to Corbin (1976), violence is both a mental and physical phenomenon, albeit as noted before we focus here upon the physical dimension only. While mentally it involves a violation of identity, physically it involves the use of force to harm or destroy objects or persons. 
Violence is often part of the abusive practices of 'brutal bosses' (Hornstein, 1996 - or leaders, mentors, coaches, or doctoral supervisors). Yet, the interaction they have with their 'willing victims' (Lipman-Blumen, 2005) has received relatively scant attention in research and practice in management. Indeed, notions of the "idealized image of leaders who transform through inspiration, passion and love" (Krantz, 2006, p. 236) remain prevalent (Antonakis, Cianciolo, \& Sternberg, 2004). However, violence finds manifestations, for instance, in the literature on destructive leadership suggesting how violent acts can harm others, create ethical failures and bad decision-making (Tierney \& Tepper, 2007).

Whiplash prompts us to contend that violence can be produced by a conscious strategy of creating shared meanings necessitating the use of physical violence by one party, and the acceptance of physical suffering by another. Overall, most research presents violence as a result of organizational dysfunctions or deviance (for background, see Geddes \& Callister, 2007). This view comes from the inability of research to politicize violence; that is, to appreciate it as inscribed in specific relationships of domination that correspond to clear objectives, rather than to unconscious or unwanted strategies. Moreover, two versions of violence need to be distinguished: (i) progressive violence for freedom, meaning that violence can be curative because "liberation and dignity cannot be recovered unless the colonized get involved in violent performances" (Kebede, 2001: 539) and (ii) repressive violence for domination, being targeted at 'breaking down' the oppressed because it sustains the power to dominate a territory and the people who inhabit it (Frazer \& Hutchings, 2008; Merleau-Ponty, 1969), although research mostly focuses upon the second form. The challenge is rather to understand how they concretely combine in specific relationships to allow violent practices to be productive, not only destructive. In other words, violence can be 'educated' (Fanon, 1961/2001); that is to say, used for curative goals, so that it becomes a practice that is recognized by actors as the potential source of a creative order. Seen in this 
light, violence can become strategic and positively instrumental (Fanon, 1961/2001) or embodied in a creative way. Whiplash clearly shows how violence is a conscious process involving physical bodies, while remaining inscribed in social encounters (Collins, 2013). Terence hurts his students, and they in turn live intense moments that will be remembered because it hurts them deeply, creating powerful memories that will make them forget the feeling of submission to violent practices, or that will give sense to this very submission. The creativity of students is partly produced by the intensity of their experience of being both brutalized and pushed upward at the same time.

The initial relationship between Andrew and Terence is one of close physical proximity, intimidation, brute force, as well as of social acknowledgement of status and recognition of a disequilibrium. Terence is powerful because Andrew admits and accepts that he is a great teacher and an accomplished conductor. Terence knows that Andrew wants to learn, and wants to learn faster and better. On that, their relationship thrives because of their fundamental agreement on the purpose and circumstances of their violent relationship. Therefore, violence here is both an instrument for achieving a goal, and an energy sui generis at the level of the individual. This energy is contained in every gesture and glance of Terence (e.g., his fist movements when he signals the band to stop playing), as well as in Andrew's everyday practice regime. It operates with physical laws that provoke a reaction that can be directed inwardly and self-destructively (e.g., when Andrew reaches his corporeal limits), or productively against the other party (i.e., when Andrew manages to overcome Terence's power by showing him that Andrew actually is the new Charlie Parker). It follows that the productive and destructive characters of violence can often work in tandem and coexist (Fanon, 1961/2001).

Further to this, Krohn-Hansen (1994, p. 370) asserts that "violence is a way to social advancement characterized by the fact that the others - victims and witnesses - are by 
definition unwilling others". Whiplash suggests that it is not always the case. The possible unwillingness of Andrew to submit his destiny to the caprices of a violent teacher is largely offset by the irreducible power of his ambition. Confident that his actions possess a veneer of legitimacy because students are all striving to be the best in their musical practice, Terence Fletcher himself is able - with certain equanimity - to pursue his ambitions by performing violently. Seeing his acts as intentional performances aiming to push students to go beyond their limits, leads us to interpret violence as co-creation of meaning between actors (i.e., leaders and followers, or teachers and students). This meaning creates a common basis for certain understandings that are not graspable by common sense, or by individuals that are outside of this relationship (i..e, any third party to the situation, see also Corbin, 1976). We suspect that there might be some readers who will probably struggle to relate to the Andrew's ambition to become the world's best drummer vis-à-vis the violent treatment he experiences from Terence.

The movie displays a relentless succession of instances of physical violence, providing a focal point around which to discuss how destructive individual behavior (i.e., that of Terence) can explain the creative extra-efforts that followers (or mentees, students or soldiers) are capable to devote because they themselves legitimize violence as a relevant means to achieve highly ambitious goals.

We must also integrate the complexity and contradictions that beset the theatrical performance that Terence puts up; speaking in the name of a collective vision (i.e., what renders the conservatory not just a conservatory but an elite conservatory) of what is a good musician, he manages to impose de facto the definition of the musical activity that best suits him. Violence is, therefore, a strategy that aims at imposing his truth as the truth of the objective relationships between musicians and between students and teachers in a given elite school where every student (and teacher) should be gripped with a fury to win and become 
the best. In order to make things come 'true', the master is authorized to speak with authority, to violently treat some chosen students (Terence: “I didn't know they allow f****** retards into the school!"), thus enforcing his moral and legitimate discourse (Bourdieu \& Wacquant, 1992). Here, the movie demonstrates that violence has actual effects on the efforts deployed by followers or students to work harder and better, not only because they are afraid, but also because they accept willingly to be part of a political economy of their corporation, school, or occupation. They should even be proud to be part of this economy, whatever that takes in terms of servitude. This enables us to understand how it is possible that violence can become a productive force at work.

To be more specific, the combination of repressive and progressive violence that the movie displays shows that the teacher/student relationship that is the central focus of Whiplash is not made of exclusive servitude but of voluntary servitude (Abensour, 2011). The movie shows practices of physical violence that seems to be acknowledged by Andrew as part of a necessary process to reach the summit. This manifests itself in the movie when, for instance, Andrew returns to the drum kit, with the flame of passion still flickering for the drumming, having abandoned it after a string of violent events (e.g., Terence throwing a chair at him and slapping him in the face). He is, therefore, voluntarily submitting himself to Terence, seemingly knowing that this very submission involves facing physical violence. However, he gives his submission to Terence, allowing the possibility of exercising this sort of power. This radical view raises not only the question of violence, but also the most fundamental question of political theory, namely, why do people desire their own domination? Deleuze and Guattari (2004) have explored the emergence of politics as relying not so much on violent domination and capture per se, but also on self-domination of individuals at the level of their own desire. Terence is intoxicated by his own power (e.g., Terence speaking to Andrew in the opening scene: “Do you know who I am?”). However, 
simultaneously the obedience of Andrew seems to come easily, almost naturally, and for some time in the movie, no signs of resistance against Terence's authority are visible. This would require the patient elaboration of practices of freedom, or 'politics of refusal' (Newman, 2010) that Andrew does not have on his agenda. As yet, he is fully involved in a hand-to-hand combat with his drum kit - and with his ambition. At first, there is no desire for autonomy on the part of Andrew, nor a need to overcome voluntary subjection to power. In a sense, he instrumentalizes his teacher to reach his goal and does not see him only as a carrier of brutality, but as a proper catalyst to reach the summit.

The hypothesis of voluntary servitude has never ceased to haunt modern political philosophy (Abensour, 2011). The very idea that individuals could decide to withdraw from politics and restrain or give up their power to resist oppression has been the object of numerous debates (see, e.g., Fromm, 1981/2010). Servitude means privation of liberty, "proceeding from a cause external to the person who endures subjection" (Abensour, 2011: 332). Voluntary servitude points to a state of no liberty, a subjection in which the cause of 'slavery' 14 is not

external but internal, as it is the subject him/herself who voluntarily submits to the master, and becomes the author of his/her own servitude through his or her own activity. Subjects are the very authors of the tyranny:

"It is therefore the inhabitants themselves who permit, or, rather, bring about, their own subjection, since by ceasing to submit they would put an end to their servitude. A people enslaves itself, cuts its own throat, when, having a choice between being vassals and being free men, it deserts its liberties and takes on the yoke, gives

\footnotetext{
14 The term 'slavery' is used by De la Boétie (1975/2008), who was born in the Périgord region of southwest France in 1530 to an aristocratic family. Yet, a major distinction must be made in terms of how de la Boétie used the terms 'slaves' in the respective socio-cultural context, and how we apply it in the context of our essay. Slaves, even in the context of de la Boétie writing, were unlikely to aspire to become world class at something. In the absence of any human dignity, they were often repressed through outright physical violence on the part of their masters or owners. Andrew, while also being exposed to physical violence by Terence, is a slave to his own ambition. He knows that it can only be realized through the violent treatment of Terence, his music teacher and master.
} 
consent to its own misery, or, rather, apparently welcomes it”. (de la Boétie, 1975/2008: 44)

With this expression of chosen subjection, one begins to reach what is the most incredible in the human species, what Abensour (2011) calls the 'mysteries of domination'. De la Boétie $(1975 / 2008)$ explores the subjective bond which ties us to the power that dominates us, which enthralls and seduces, blinds and mesmerizes us. Servitude, then, can be a condition of our own making, except in situations where pure force is exercised, which helps to understand power relationships as practices of self-domination.

According to de la Boétie (1975/2008), far from being assigned to the passive role of accepting the domination without any counter gesture, the 'slaves' participate in it which means that they are its active artisans. Slaves in this sense are never deceived, nor fundamentally abused, but willing. Instead of the idea that consent is 'manufactured' from exogenous forces, acceptance receives active, even fanatical, support. For de la Boétie (1975/2008), humans are made subservient through affects like fascination, through adoration of 'the name of one man alone', by the virtue of someone being 'The One', either being the king, the dictator or the master; subjection is produced by the appearances created around an individual who seems to fulfill the subordinates' or followers desires ${ }^{15}$. In Whiplash, we observe the dual construction of Terence as both "The One" and as the instrument for Andrew to become the best. Genuine respect and fear, which allows the corporeal dimension of violence to be expressed, goes hand in hand with strategy which allows the instrumental dimension of violence to be expressed.

The result of this conception is that the very question of politics of interpersonal relationships at work is less a matter of turning toward the rulers, leaders, or managers and sifting through their system of domination, but more a matter of the ruled and the ways they choose to participate in their own subjugation. Put differently, Whiplash alerts management

\footnotetext{
${ }^{15}$ We do see parallels of this argument in relation to what seems to be unfolding in today's US politics.
} 
researchers to examine interpersonal relationships through the practices of strategic obedience rather than through the practices of domination. The movie is an interesting instance of that theoretical reversal. It shows a fundamentally self-negating activity which also suggests that it is up to Andrew to put an end to his self-sacrifice, to the self-destructive relationship that he seems to accept for most parts of the movie. This encourages us to think that the key to freedom is in the hands of the people, rather than in any decision from the master to untie the chains of subordinates. In a way, a careful reading of de la Boétie $(1975 / 2008)$ suggests that there is a central complication in any relationship of power: the individual's will to be free is always surpassed by a will to live in subordination for assumed reasons. This conundrum is central to the political understanding of violence. That is, it helps grasp violence as being permitted by the priorities of individuals to their goals as they see them at a given moment - as opposed to concerns over their dignity or emancipation. Subjection is grounded on the implicit acknowledgment of the rationality and efficiency of the teaching method, a kind of universal recognition that without self-sacrifice and suffering, no true ambition can be achieved. Submission to violent authority does not appear to go against one's self. It is not an assault against reason, nor even a deliberate masochist selfdestruction, but rather a way of gaining access - through sacrifice and rational acceptance - to the very world of the teacher, to the possibility of becoming the teacher, of becoming better than him.

\title{
REWRITING THE ROLE OF PASSIONS IN BUREAUCRACIES
}

\author{
Weber himself provides some solutions to the conundrum expressed in this essay around the \\ role of violence in the production of efficient bureaucracies. On the one hand, he says that \\ "bureaucracy develops the more perfectly, the more it is 'dehumanized', the more completely \\ it succeeds in eliminating from official business love, hatred, and all purely personal,
}


irrational and emotional elements which escape calculation" (Weber, 1922/1978: 975). Bureaucracy is, therefore, for him a form of organization that requires formalistic impersonality: "sine ira et studio, without hatred or passion, and hence without affection or enthusiasm ... Everyone is subject to formal equality of treatment; that is everyone in the same empirical situation" (Weber, 1922/1978: 225). Since then, most attempts of organizational scholarship sought to discuss the difficulties of a dialectic between human passions and administrative/organizational regulations. Later, Jaques' (1976) general theory of bureaucracy posited "an intensely human situation, founded upon a psychologically and emotionally subtle relationship", a situation to be managed properly because otherwise, a "potential source of energy for social violence" could arise, which was considered as a problem (pp. 66-68). Emotional neutrality, or the 'silence of feelings' (Albrow, 1992) was long considered as a condition of efficiency and a hallmark within organization theory, although the sociology of emotions (Fineman, 1993; Hochschild, 1983) has permeated the rationalistic bulwark of most research in organizations over the last decades.

However, what is related to passionate relationships or interactions is still often considered as deviance, or pathological irrationality. Most subsequent writers on bureaucracy have insisted upon the faceless official as the central figure of the bureaucratic machinery (Du Gay, 2000). This essay shows such characterizations can be misleading because bureaucracies are inhabited by individuals whose everyday encounters essentially involve vital and passionate experiences. Weber himself was mostly interested in the relations between rationality and irrationality (Albrow, 1992). He did not exclude enthusiasm, or unreserved dedication to a cause or an exceptional achievement, as possible forms of commitment in bureaucracies, even though he simultaneously crafted a political and administrative pattern that has been interpreted and translated many times as a countercreative cage. To be sure, the movement of de-rationalization of organizations (and the 
individuals that make up organizations) started early in the 1980s, when a 'magical' rhetoric of success emerged that would be theorized as being rooted in values, love and empathy. What was then celebrated, among others by Peters and Austin (1986: 292), was "commitment, passion, zest, energy, care, love and enthusiasm", all affective states that can be found in Whiplash, counterbalanced by the expression of sheer violence. The significance of human passion in organizations was made legitimate in post-Weberian scholarship (Albrow, 1992). A closer reading of Weber would have revealed that in his work on Science as a Vocation, he already largely insisted upon the processes of frenzy, inspiration and passionate devotion which characterized scientific work, in a similar way as artistic work (Weber, 1921/1946). He made possible the framing of passions and rules as combinable forces, instead of opposing the repressive and drying energy of administrative logics to the progressive and creative energy of entrepreneurs (Du Gay, 2000).

As we suggested before, Whiplash offers rich and fresh insights into how violence and passion can be integral to the everyday functioning of bureaucracies. It provides a nuanced understanding of how an artist, however locked in a relation of subordination, disciplining himself and being disciplined by the power of his master, unlocks enough creative energy to navigate the seemingly rigid instrumental, logical and rational aspects of the discipline that often penetrates bureaucracies. Progressing through violence engages Andrew in a broader repertoire of sensory experiences; he can feel this experience in the corporeal perturbations that he is living (hurting himself, bleeding, crying...), being at one with his drumkit and his sticks. Far from minimizing creativity, violence acts here as a creative trigger, because it pushes Andrew's sensorial experience and fusion with his instrument.

In this practice, we see discipline as being an obvious main component, as in any bureaucracy. Weber saw discipline - for him a necessary characteristic of bureaucracy and a simple implicate of hierarchy - as arising from military discipline, or "the womb of discipline 
in general". He says that bureaucracy itself is "the most rational child of discipline" (Weber, 1922/1978: 642), and that organizations are "great educators in discipline" (p. 647). But Merton (1952: 365) demonstrated that "discipline can be effective only if the ideal patterns are buttressed by strong sentiments which entail devotion to one's duties (...) The efficiency of social structure depends ultimately on infusing group participants with appropriate attitudes and sentiments". Whiplash illustrates how everyday human feelings and vitality can be compatible with the discipline that permeates bureaucracies.

\section{THE FINAL SCENE AND CONCLUSION}

Having woven together key features of Whiplash with the literatures on violence, passions, and bureaucracies, we can now turn to the final scene. Here, it manifests itself that the world-class solo performed by Andrew confirms that Terence's model of learning through productive violence - and its passionate manifestations - a can ultimately lead to excellent performance in situations when a student appears initially as a willing victim. As the final scene underscores, however, Andrew makes the passage from willing victim to a willing victor, thus indicating a fundamental reversal of the teacher-student relationship.

Consistent with prior 'needling' tactics, Andrew had left the stage following the deliberate humiliation by Terence in front of a high-profile audience, including talent scouts. It is worth recalling that Andrew testified against Terence on condition of anonymity, but Terence reveals to Andrew that he knows that it was him who testified against him. So for Terence, this was a moment of revenge that is best served cold, the ultimate way to exercise revenge in such a way that would bury Andrew's hope and ambitions for good. He does so by leading the band with a piece unfamiliar to Andrew, thereby locating the fault of the failed performance exclusively in the hands of Andrew. 
Having left the stage, Andrew is being hugged and consoled by his father, who awaits him backstage ready to play the role of the compassionate father. Yet, before he can fully play that role, the viewer witnesses a quite discernable metaphorical 'click', a release of utter resolution and conviction that he can show Terence that he is, after all, the next Charlie Parker. Returning to the stage, Andrew sheds the chains of repression, and literally takes charge of the situation by starting to provide the rhythm for the band to cue in - against the will of the dismayed-looking and fuming Terence (whose first visceral reaction is "I'm gonna gouge out your mother******* eyes"). As Terence bends over the drum to spit out these words, Andrew gives him a slight superior smile and hits the cymbals (which, in turn, hit Terence's face). Now Andrew inflicts physical violence on Terence, if only moderately so compared to the violence he suffered at the hand of Terence. Terence continues to ask "Andrew, what you are doing?" to which Andrew astonishingly replies "I'll cue you!". What follows is an extraordinary drum performance - to the point of blood drops being sprinkled all over the drum kit. Intriguingly, Terence willingly assumes the role of a passive mentor that has relinquished control over his subject, one he previously controlled through violence. For Andrew, the ensuing drum solo marks a sudden shedding of all the repression he ever experienced under Terence's rule. On finishing the solo, Terence's face signals a smiling expression of relief and approval, and it is that smile that has a highly cathartic effect on Andrew. All that Andrew ever dreamed of, all that physical hardship that he endured, not only makes sense now, but, perhaps more importantly, breaks the relationship of voluntary servitude and renders Andrew emancipated from the influence of Terence. He has attained his cherished goal to become a world-class drummer.

Early on in our essay we have highlighted that an analysis of Whiplash is relevant to management and organization studies for at least two reasons. First, the movie shows how the everyday practice of violence at work can drive learning and excellent performance. And 
second, Whiplash permits a new reading of how passions influence the production of the efficiency of bureaucracies. Against this backdrop, the final scene offers a powerful occasion to examine the productive relationship between the exaltation of passions and the discipline of bureaucracy. Passionate experiences and instrumental rationalities intermingle to inform both the efficient organization (because of the success of a teacher), and the individual exceptional performance of one of its students.

However, this creates a conundrum; we see people suffering on the one hand, while acknowledging on the other hand that the harshness of discipline, the choice of willing obedience and their unalterable ambition have produced something they could not even imagine. The very violence of everyday encounters at work suggests once again that their experience in this bureaucracy is fundamentally human. Thus, it shows that we are more than rule followers, and that we can avoid institutions draining our agency of its richness and color. Andrew's eventual victory suggests that we have not yet become completely bureaucratized through discipline and honing of technical expertise (Gouldner, 1954), precisely because passions are central in the shaping of success - maybe more than rules. It follows that Andrew and Terence's efforts cannot be cut off from their humanity, even though they reflect deep internal tensions (Ashcraft, 2006). The dilemma in the process of organizing is amplified in this movie by the everyday expression of violence. Violence functions amid enduring incongruities arising from the unexpected alliance between a conception of work based on discipline and endured hardship on the one hand, and creativity and imagination on the other. Whiplash shows how creativity, when unleashed violently, can "take us beyond bureaucratic boxes" (Morgan, 1997: xxix). By contrast, the tendency in organization and management theory toward abstract and irenic views of organizations makes it possible for everyone involved in specific workplaces to "imagine that the violence upholding the system is somehow not responsible for its violent effects" (Graeber, 2012: 
114). Consequently, Whiplash helps us to deal more honestly with violence in bureaucracies instead of marginalizing the topic. This marginalization, like the marginalization of anger at work (Lindebaum \& Gabriel, 2016), can indeed have disastrous consequences, especially if one party does not voluntarily submit to the violent treatment of a leader or teacher (as Andrew does). In such cases, organizational violence, when ignored or denied, breeds more resentment and turns into a vicious circle of suffering and physical harm in organizations.

The question whether not only world-class musicians, superstar footballers, researchers, astronauts, or any kind of 'extreme worker' (see, e.g., Granter, McCann, \& Boyle, 2015), but also workers employed in high-commitment organizations, can be motivated enough to explore their physical, cognitive and technical limits, is a basic challenge for contemporary management. Contemporary work situations necessitate more and more that we understand the meaningfulness of suffering in contexts where individuals experience the inability to withdraw from obligations (e.g., being unable to leave one's job, see Lindebaum, 2017), thus leading to 'vital exhaustion' (Preckel, Känel, Kudielka, \& Fischer, 2005). In response to the duress of the workplace, we may indeed observe the development of management practice whose main rhetorical and practical politics would be to cynically stigmatize weakness and renouncement, while at the same time develop a cult of commitment through self-sacrifice, of freely chosen pain to win or achieve at all costs. This would obviously fit the current competitive workplace, where individuals feel everyday the brutal pressure of a culture of self-dedication or self-optimization (see, e.g., Cederström \& Spicer, 2015), where managerial systems permit to evaluate the efficacy of self-sacrifice, and where individuals may not dare take the freedom to do anything other than give everything to their job.

Therefore, this raises the question of the current radicalization of management, and of its ethical corollary; that is, the belief that people can become better if - and only if - they 
learn to become better through transformative events like the 'crucibles of leadership' (Bennis \& Thomas, 2002). These are life-threatening and potentially violent moments in life that challenge one's belief systems and core values, and that would show the ability of certain people to conquer adversity, to emerge stronger and more committed than ever. But, as we have shown through our analysis of Whiplash, the violent relationship between Andrew and Terence only functions because Andrew's participation in that relationship is voluntary. In the absence of this voluntary participation, the theorizing presented in our essay is less likely to hold. On a practical level, the realities at work for employees facing violent leaders or managers may turn proverbially to be a hell. Seen in this light, the analysis of Whiplash provides both an opportunity and a caution; it invites future theorizing around the role of violence - and its passionate manifestations - as a driver for excellent performance in cases when both parties to the exchange agreed to it, while also alerting us to the potential suffering of employees if violence is inflicted on them without their voluntary consent.

\section{REFERENCES}

Abensour, M. 2011. Is there a proper way to use the voluntary servitude hypothesis? Journal of Political Ideologies, 16(3): 329-348.

Albrow, M. 1992. Sine Ira et Studio - or Do Organizations Have Feelings? Organization Studies, 13(3): 313-329.

Antonakis, J., Cianciolo, A. T., \& Sternberg, R. J. 2004. Leadership - Past, Present and Future. In J. Antonakis, A. T. Cianciolo, \& R. J. Sternberg (Eds.), The nature of leadership: 3-15. Thousand Oaks: Sage.

Ashcraft, K. L. 2006. Feminist-Bureaucratic Control and Other Adversarial Allies: Extending Organized Dissonance to the Practice of "New" Forms A previous version of this paper received a Top Paper award from the National Communication Association's Organizational Communication Division. Communication Monographs, 73(1): 5586.

Bennis, W. G., \& Thomas, R. J. 2002. Crucibles of leadership. Harvard business review, 80(9): 39-45, 124.

Bourdieu, P., \& Wacquant, L. J. D. 1992. An invitation to reflexive sociology. Chicago: IL.: University of Chicago Press.

Cajiao, J., \& Burke, M. J. 2016. How Instructional Methods Influence Skill Development in Management Education. Academy of Management Learning \& Education, 15(3): 508-524.

Cederström, C., \& Spicer, A. 2015. The Wellness Syndrome. Cambridge, UK: Polity Press.

Clegg, S. R. 2006. Why is Organization Theory so Ignorant? The Neglect of Total Institutions. Journal of Management Inquiry, 15(4): 426-430. 
Collins, R. 2013. Entering and leaving the tunnel of violence: Micro-sociological dynamics of emotional entrainment in violent interactions. Current Sociology, 61(2): 132-151.

Confortini, C. C. 2006. Galtung, Violence, and Gender: The Case for a Peace Studies/Feminism Alliance. Peace \& Change, 31(3): 333-367.

Corbin, J. R. 1976. An anthropological perspective on violence. International Journal of Environmental Studies, 10(1): 107-111.

de la Boétie, E. 1975/2008. Politics of Obedience: The Discourse of Voluntary Servitude. Auburn, AL: Ludwig von Miese Institute.

de Tocqueville, A. 1889/2002. Democracy in America. Washington, DC: Regnery Publishing

Deleuze, G., \& Guattari, F. 2004. A Thousand of Plateaus: Capitalism and Schizophrenia. Minnesota: University of Minnesota Press.

Du Gay, P. 2000. Praise of Bureaucracy. London: Sage.

Fanon, F. 1961/2001. The Wretched of the Earth. London: Penguin Books.

Fineman, S. (Ed.). 1993. Emotion in Organizations. London: Sage.

Frazer, E., \& Hutchings, K. 2008. On Politics and Violence: Arendt Contra Fanon. Contemporary Political Theory, 7(1): 90-108.

Fromm, E. 1941/2011. Escape from Freedom. New York: Ishi Press.

Fromm, E. 1981/2010. On Disobedience: Why Freedom Means Saying "No" to Power. New York: HarperCollins.

Gabrielsson, A. 2001. Emotion perceived and emotion felt: Same or different? Musicae Scientiae, 5(1_suppl): 123-147.

Geddes, D., \& Callister, R. R. 2007. Crossing the line(s): A dual threshold model of anger in organizations. Academy of Management Review, 32(3): 721-746.

Gouldner, A. W. 1954. Patterns of Industrial Bureaucracy - a case study of modern factory administration. New York: Free Press.

Graeber, D. 2012. Dead zones of the imagination: On violence, bureaucracy, and interpretive labor. The 2006 Malinowski Memorial Lecture. HAU: Journal of Ethnographic Theory, 2(2): 105-128.

Granter, E., McCann, L., \& Boyle, M. 2015. Extreme work/normal work: Intensification, storytelling and hypermediation in the (re)construction of 'the New Normal'. Organization, 22(4): 443-456.

Hearn, J. 1994. The Organization(s) of Violence: Men, Gender Relations, Organizations, and Violences. Human Relations, 47(6): 731-754.

Hochschild, A. R. 1983. The managed heart: commercialisation of human feeling. Berkeley: University of California Press.

Hornstein, H. A. 1996. Brutal bosses and their prey: How to identify and overcome abuse in the workplace. New York: Riverhead Books.

Jaques, E. 1976. A General Theory of Bureaucracy. London: Heinemann Educational.

Johns, G. 2017. Incorporating Context in Organizational Research: Reflections on the 2016 AMR Decade Award. Academy of Management Review.

Kebede, M. 2001. The Rehabilitation of Violence and the Violence of Rehabilitation. Journal of Black Studies, 31(5): 539-562.

Krantz, J. 2006. Leadership, betrayal and adaptation. Human Relations, 59(2): 221-240.

Krohn-Hansen, C. 1994. The Anthropology of Violent Interaction. Journal of Anthropological Research, 50(4): 367-381.

Lindebaum, D. 2017. Emancipation through Emotion Regulation at Work. Cheltenham, UK: Edward Elgar.

Lindebaum, D., \& Ashkanasy, N. 2017. A 'new' heart for institutions? Some elaborations on Voronov and Weber. Academy of Management Review, 42(3): 548-551. 
Lindebaum, D., \& Gabriel, Y. 2016. Anger and Organization Studies - From Social Disorder to Moral Order. Organization Studies, 37(7): 903-918.

Lindebaum, D., Jordan, P. J., \& Morris, L. 2016. Symmetrical and asymmetrical outcomes of leader anger expression: A qualitative study of army personnel. Human Relations, 69(2): 277-300.

Lipman-Blumen, J. 2005. The allure of toxic leaders - Why we follow destructive bosses and corrupt politicians and how we can survive them. Oxford, UK: Oxford University Press.

Merleau-Ponty, M. 1969. Humanism and Terror. Boston: Beacon Press.

Merton, R. K. 1952. Reader in bureaucracy. Glencoe, Ill: The Free Press.

Morgan, G. 1997. Imagin-i-zation: New mindsets for seeing, organizing, and managing. San Francisco: Berrett-Koehler.

Newman, S. 2010. Voluntary Servitude Reconsidered: Radical Politics and the Problem of Self-Domination Anarchist Developments in Cultural Studies, 1: 31-49.

Perttula, K. H., \& Cardon, M. S. 2011. Passion. In G. M. Spreitzer, \& K. S. Cameron (Eds.), The Oxford handbook of positive organizational scholarship: 190-200. New York: Oxford University Press.

Peters, T., \& Austin, N. 1986. A Passion for Excellence. London: Collins.

Preckel, D., Känel, R. v., Kudielka, B. M., \& Fischer, J. E. 2005. Overcommitment to work is associated with vital exhaustion. International Archives of Occupational and Environmental Health, 78(2): 117-122.

Ronay, B. 2016. José Mourinho and injuries: a long, public, darkly productive relationship. Guardian, 7 November - (Retrieved from https://www.theguardian.com/football/blog/2016/nov/07/jose-mourinho-manchester-unitedluke-shaw-chris-smalling-injuries on 25 November 2016).

Sandberg, J. 2005. How Do We Justify Knowledge Produced Within Interpretive Approaches? Organizational Research Methods, 8(1): 41-68.

Smith, L. 2007. The Few and the Proud: Marine Corps Drill Instructors in Their Own Words New York: W. W. Norton Company.

Terkel, S. 1974. Working people talk about what they do all day and how they feel about what they do. New York: Pantheon Books.

Tierney, P., \& Tepper, B. J. 2007. Introduction to The Leadership Quarterly special issue: Destructive leadership. The Leadership Quarterly, 18(3): 171-173.

Travers, P. 2014. Whiplash. Rolling Stone, October 9(Retrieved from http://www.rollingstone.com/movies/reviews/whiplash-20141009 on 21 April 2017).

Vallerand, R. J., Blanchard, C., Mageau, G. A., Koestner, R., Ratelle, C., Leonard, M., Gagne, M., \& Marsolais, J. 2003. Les passions de l'ame: on obsessive and harmonious passion. Journal of personality and social psychology, 85(4): 756-767.

Voronov, M., \& Weber, K. 2016. The Heart of Institutions: Emotional Competence and Institutional Actorhood. Academy of Management Review, 41(3): 456-478.

Weber, M. 1921/1946. Science As a Vocation. In H. Gerth, \& C. W. Mills (Eds.), From Max Weber. New York: Oxford University Press.

Weber, M. 1922/1978. Economy and Society: an Outline of Interpretative Sociology. Berkeley, CA: University of California Press.

\section{Author details}

Dirk Lindebaum is Professor in Organisation and Management at Cardiff Business School.

He has developed a wider curiosity for diverse notions, constructs, methods and controversies 
in recent years. This appetence for learning and searching led him to pursue a significant body of research around emotion at work, the latest culmination of which is his book Emancipation Through Emotion Regulation at Work (published by Edward Elgar in 2017). In addition, his interest in emancipation has also led him to engage with the field of organizational neuroscience, where emancipation refers to the liberation from repressive scientific discourses and technologies which have potentially dehumanizing consequences for individuals at work. Read more about his work at dirklindebaum.EU.

David Courpasson is Professor of Sociology at Emlyon Business School, France and Professor at Cardiff Business School, Cardiff University, UK. He is the Director of EmlyonOCE Research Centre. He was the Editor in Chief of Organization Studies 2008-2013. His current research and writing interests are focused around the multiplicity of resisting processes and how they permit actors to engage with and modify power relationships. He is also interested in understanding how workplace changes affect identities and social relationships within organizations and institutions. His work has been published in diverse journals such as Organization Science, Organization Studies, Organization, Entrepreneurship, Theory and Practice, Journal of Business Venturing and Journal of Management Studies. He has recently edited The Sage Handbook of Resistance (with Steven Vallas). 